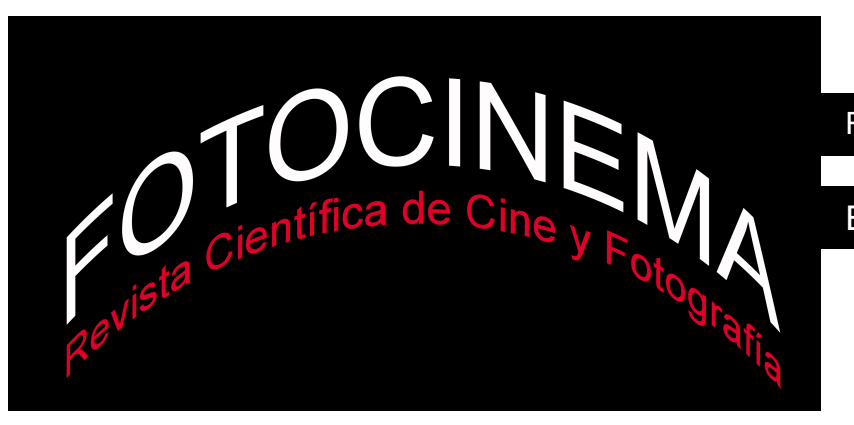

\title{
Documentales sobre el 15-m: una modalidad plural para una revolución plural
}

\section{Documentaries on 15-m: A plural modality for a plural revolution}

Carmen Moreno-Nuño

University of Kentucky, Estados Unidos morenonuno@uky.edu

\section{Resumen:}

La deficiente cobertura informativa que los medios llevaron a cabo sobre el 15M en 2011, además de otorgar a los documentales producidos sobre el tema la capacidad de intervenir en el imaginario social, desveló la dificultad de representar esta movilización. En este artículo se analizan los documentales \#Indignados. Del 15M al 20N, 15M: "Excelente, Revulsivo, Importante", \#Acampadasol: historia de una ciudad, Falsos horizontes y Libre te quiero para mostrar cómo la variedad de modos documentales - usando el esquema conceptual de Bill Nichols- usados por los cineastas revela que el 15-M es un fenómeno difícilmente encasillable dentro de un único tipo de representación.

\begin{abstract}
:
The biased media coverage on 15-M in 2011 grants the documentaries produced on this topic the ability to intervene in the social imaginary; at the same time, it reveals the difficulty of representing this social movement. In this article I will study the documentaries \#Indignados. Del 15M al 20N, 15M: "Excelente, Revulsivo, Importante”, \#Acampadasol: historia de una ciudad, Falsos horizontes and Libre te quiero in order to show how the diversity of documentary modes - using Bill Nichol's conceptual scheme- used by the authors reflects that $15-\mathrm{M}$ cannot be easily confined within the conventions of a unique type of representation.
\end{abstract}

\section{Palabras clave:}

15-M; movimiento indignado; documental; crisis económica; Basilio Martín Patino; modos documentales.

\section{Keywords:}

15-M; The Outraged; Documentary; Economic Crisis; Basilio Martín Patino; Documentary Modes. 


\section{Entendiendo el 15-M}

El año 2011 quedó convertido en icono de protesta social por los movimientos que, a escala global, surgieron durante la primavera y el verano dando voz a una indignación popular que se expresó en contextos tan diversos como las Primaveras Árabes, la Aganaktismenoi griega, la Revolución de Islandia, el movimiento J14 en Israel, Occupy Wall Street en Estados Unidos, la Geração à Rasca de Portugal y el 15-M en España. El desacuerdo y la confrontación fueron la respuesta a las consecuencias devastadoras que estaba teniendo la crisis económica desde 2007, las cuales se traducían en deuda, inseguridad y humillación para gran parte de la ciudadanía. Usando como principal estrategia la movilización no violenta, un número sin precedentes de ciudadanos de numerosos países se congregaron en cientos de lugares para alzar su voz contra líderes políticos y plutócratas y para dar forma a nuevas maneras de activismo. Interrogando la legitimidad de las élites políticas y económicas, las protestas encaraban dos problemas diferentes pero claramente interrelacionados. En países como Egipto, Libia, Marruecos, Siria y Túnez las demandas de reforma política buscaban reconstruir procesos democráticos; en naciones como Bélgica, Francia, Grecia, Reino Unido, Estados Unidos y España las movilizaciones reflejaban sobre todo el resentimiento contra unas prácticas liberales que, agravadas por el ejercicio corrupto del poder, habían incrementado la injusticia social convirtiendo la precariedad en el único modo de vida posible. La ola de indignación se prolongó en movimientos como Yo soy 132 en México o Nuit Debout en Francia.

En España, el 15-M o movimiento de los “indignados” se generó a raíz de la manifestación que diversos colectivos convocaron para el 15 de mayo de 2011, la cual terminó con unas cuarenta personas acampando de manera espontánea en la céntrica plaza Puerta del Sol de Madrid para pasar esa noche. Esta pequeña concentración se transformó rápidamente en acampadas de miles de personas en varias plazas públicas de todo el país 
durante unas tres semanas, especialmente multitudinarias en Madrid y Barcelona, y una serie de protestas pacíficas con la intención de promover una democracia más participativa alejada del bipartidismo PSOE-PP y de la influencia de bancos y corporaciones. Las consecuencias más visibles del movimiento fueron las actividades contra los desahucios, la creación del partido político Podemos y el final del bipartidismo ${ }^{1}$. Desde sus comienzos, el 15-M fue objeto de una cobertura mediática muy criticada por los acampados por distorsionar la realidad. El género del documental es, por su parte, comúnmente asociado con la verdad histórica. El cine ha sido tradicionalmente testigo de revoluciones, insurgencias, disturbios, levantamientos y proyectos emancipadores, acercándose a ellos desde la doble mirada de la ficción y del reportaje. La manipulación mediática denunciada por los indignados otorga a los documentales sobre el 15-M una relevancia especial por su capacidad para actuar como vehículos que pueden ayudar a esclarecer los hechos históricos. Por ello la captación en vivo del acontecimiento - reportaje- es fundamental: todos los films que se van a analizar en este ensayo han sido filmados en los mismos lugares donde suceden los hechos y con sonido en directo. El mantener la integridad de la relación con el contexto original añade credibilidad al documental al afianzar el deseo de inmediatez del espectador y alimentar la creencia, por ilusoria que esta pueda ser, de que el trabajo fílmico ofrece un acceso directo a lo real (Spence \& Navarro, 2011, p. 219). De la misma manera, el sonido en directo posee un especial tipo de autoridad, ya que es entendido como evidencia material o rasgo del mundo físico que es capturado por el micrófono.

En su intento por cambiar la distorsionada imagen oficial sobre los indignados, los documentales \#Indignados. Del 15M al 20N (Antón Verdaguer, 2011), 15M: "Excelente, Revulsivo, Importante" (Stéphane M. Grueso, 2012), \#Acampadasol: historia de una ciudad (Adriano Morán, 2011), Falsos horizontes (Carlos Serrano Azcona, 2013) y Libre te quiero

\footnotetext{
${ }^{1}$ Las asociaciones Plataforma de Afectados por la Hipoteca y Stop Desahucios han sido especialmente eficaces en su lucha para reducir el número y la gravedad de los efectos de los desahucios. Se estima que en 2012 se ejecutan 175 desalojos diarios en España.
} 
(Basilio Martín Patino, 2012) cumplen la importante función de intervención en una res publica en la que pretenden imponer un nuevo imaginario colectivo. Dentro de las distintas formas que toman las revoluciones en las imágenes -intervención, persistencia y usos - este ensayo busca estudiar los mecanismos utilizados por dichos documentales, especialmente la estructura organizativa y el uso de técnicas formales, para elaborar la realidad después del momento de la captación de las imágenes rodadas: estamos por tanto en el terreno de la intervención. Para ello voy a valerme de la conocida teoría de los modos documentales que Bill Nichols desarrolla en Introducción al documental $^{2}$. La tesis que voy a proponer es que la diversidad de modos documentales que se observan en los films analizados responde a una pluralidad de significaciones que es inherente al 15-M. Como ha observado Nichols, las distintas coyunturas históricas han favorecido la aparición de una variedad de tipos de documentales que van desde el poético hasta el expresivo, en una tipología de configuraciones expresivas que pone en relación las cualidades internas al texto fílmico con las expectativas epistemológicas que se asocian al cine de no ficción. Si llevamos la teoría de Nichols al contexto español, podríamos pensar en el documental de memoria histórica producido en el siglo XXI sobre la Guerra Civil, en el cual predomina claramente el modo participativo por la importancia cobrada por el testimonio y el relato oral como ruptura con el pacto de silencio. La representación fílmica del 15-M destaca, por el contrario, por una diversidad de modos documentales que tiene que ser explicada: la novedad radical que supone este movimiento de intención revolucionaria no es fácilmente reducible a un molde único, forzando a los cineastas a optar por unas propuestas discursivas que son muy diferentes entre sí. Con todo, debe tenerse en cuenta no solamente que las diferentes formas posibles de representar un hecho no corresponden únicamente a la pluralidad intrínseca del mismo sino, sobre todo, que el corpus escogido aparece dominado por formas consensuales ajustadas a unas categorías prefijadas (las de Bill

\footnotetext{
2 Nichols establece seis modos documentales: expositivo, poético, observacional, participativo, reflexivo y expresivo.
} 
Nichols). Se trata por tanto de un corpus que representa una realidad radical pero que, al carecer de voluntad rupturista desde el punto de vista formal, no es en sí mismo revolucionario.

El carácter novedoso e inédito del 15-M ha sido señalado en los distintos estudios monográficos que se han dedicado al tema, entre los que destacan varios números especiales de revistas literarias: Cinco años después del 15M: narrativas de la crisis económica y política en $452^{\circ} \mathrm{F}$, La imaginación sostenible: culturas y crisis económica en la España actual en Hispanic Review, y Spain in Crisis: 15-M and the Culture of Indignation en Journal of Spanish Cultural Studies 3 . Los estudiosos han reincidido en la naturaleza original, innovadora, multifacética y heterogénea de este movimiento. Bryan Cameron ha observado que, en su intento de transformar el deficiente sistema democrático actual, "the 15-M has managed to promote a collective heteronomy by evading the parliamentary system" (2014, p. 3). En su carácter revolucionario, este movimiento pasó a repensar lo que era considerado como un desfasado "pluralism whose legitimacy is only recognized in the private sphere" (Mouffe citada en Cameron, 2014, p. 3), pasando dicho pluralismo de la esfera privada a la pública. El trabajo de los "indignados" destacó por su capacidad para producir nuevos imaginarios, articular subjetividades alternativas y galvanizar las pasiones de los ciudadanos españoles, lo que dio como resultado una diversidad de expresiones de insurgencia intelectual y artística. La aproximación horizontal y no elitista a la cultura, además de cortocircuitar la ideología neoliberal que se basa en la competición y el individualismo, dio lugar a un modelo de convivencia en el que prevalecieron las identidades colectivas. En este sentido, Albert Jornet Somoza (2016, p. 2) ha apuntado a las articulaciones discursivas y culturales que surgen de estos nuevos espacios privilegiados de

3 Cinco años después del 15M: narrativas de la crisis económica y política en $452^{\circ} \mathrm{F}$ (n. 15 , 2016), La imaginación sostenible: culturas y crisis económica en la España actual en Hispanic Review (n. 84, 2012), y Spain in Crisis: 15-M and the Culture of Indignation en Journal of Spanish Cultural Studies (n. 15, 2015). 
resistencia como instrumentos de imaginación poética que permiten instalar “otros mundos y subjetividades posibles en nuestros horizontes intelectivos”.

Resaltando la capacidad del 15-M para incluir a muchos tipos de gente diferente, Luis Moreno-Caballud ha subrayado el hecho de que más del 80\% de los españoles manifestaran su apoyo a las movilizaciones en junio de 2011, lo que "se puede leer como un síntoma de la voluntad colectiva de explorar otras formas de vida” (2012, p. 549). Entendiendo que las narraciones de vidas precarias popularizadas a raíz de la crisis económica intentaban dar visibilidad a las historias de pobreza como piezas más fundamentales de la historia nacional, Germán Labrador Méndez ha notado que en las asambleas la gente traía su experiencia pero también la de otros, "para que en la plaza estuviesen Todos" (cursiva en el original) (2012, p. 573), en un ejercicio de inclusividad que rompió con los hábitos sociopolíticos desarrollados durante la democracia española. Ángel Luis Lara ha hablado de "una auténtica experiencia de ruptura [...] que ha posibilitado la emergencia y la visibilización de nuevas disposiciones mentales y políticas” (2016, p. 654). Como ha puesto de manifiesto el nuevo tejido de prácticas y procesos de innovación en el acceso a la cultura - descarga de contenidos en internet, ética hacker, ciberactivismo-, la revolución del 2011 careció de un sujeto particular por anclarse en unas lógicas post-identitarias que buscaban redefinir lo colectivo y común. Por su parte, Amador Fernández-Savater ha reflexionado sobre la relación que existe entre la Transición y el 15-M: los modos atípicos de politización de este último, que no pueden englobarse fácilmente en movimientos sociales alternativos o antisistema, contestaron la Cultura de la Transición como discurso hegemónico que mediante el consenso impuso la democracia neoliberal como único marco posible de convivencia y organización de lo común. Al indefinir la definición o desidentificar la identidad -ni PP ni PSOE, ni monárquicos ni republicanos, ni izquierda ni derecha, ni reformistas ni revolucionarios-, el 15-M abrió un espacio común para todos en el que predominaron las "identidades no identitarias” como "indignados", “personas”, “el 99\%” e incluso la Puerta del 
Sol como personaje colectivo (2012, p. 679). Se trató de una nueva disposición colectiva hacia la realidad: "Es una rebelión de los públicos y las audiencias, una toma de palabra masiva, una apertura de lo posible, la propuesta de otros temas de discusión y otros modos de hacer. El nacimiento de un nuevo poder social" (cursiva del autor) (Fernández-Savater, 2012, p. $681)$.

Centrándose en el carácter innovador e inédito del 15-M, este ensayo se propone analizar la representación de este movimiento en los documentales \#Indignados. Del 15M al 20N, 15M: "Excelente, Revulsivo, Importante", \#Acampadasol: historia de una ciudad, Falsos horizontes y Libre te quiero. Aun a riesgo de utilizar un criterio de selección identitario que puede contradecir el espíritu global del $15-\mathrm{M}$, este estudio se ciñe al género del documental y, dentro de este, a un grupo de obras que son de nacionalidad española y que tienen como idioma el castellano. Por eso el film catalán $E l$ despertar de les places. Un any de 15M (2012) de Lluc Güell Fleck y Jordi Oriola i Folch no es analizado. La inclusión de documentales dirigidos por cineastas de otros países, como Vers Madrid (2013) del francés Sylvain George; o que contienen referencias al $15-\mathrm{M}$ sin ser este su tema principal, como Informe General II (2016) de Pere Portabella y Tres instantes, un grito (2013) de Cecilia Barriga; o que derivan del acontecimiento pero no lo mencionan directamente como La matança del porc (2012) y Murieron por encima de sus posibilidades (2014) de Isaki Lacuesta y Clase Valiente (2016) de Víctor Alonso, desbordaría el objeto de estudio abarcable en estas páginas ${ }^{4}$. Este texto corre por tanto el riesgo de dejar fuera algunas películas relevantes sobre el 15-M, ya que el corpus de obras que inciden en este acontecimiento es amplio. Por eso se propone como una primera mirada, no

\footnotetext{
4 Vers Madrid es un documental experimental que, a modo de noticiario cinematográfico, fotografía la realidad caótica del 15-M como revuelta social. Informe General II inscribe el 15-M dentro de una genealogía histórica que estudia la crisis que aqueja al modelo políticosocial de las últimas décadas. Tres instantes, un grito trata sobre las protestas populares en Madrid, Wall Street y Chile. El documental Clase valiente investiga la importancia del lenguaje político en nuestra forma de entender el mundo. El cortometraje La matança del porc y el largometraje de ficción Murieron por encima de sus posibilidades abordan la posibilidad de que un enloquecido plan pueda salvar la economía española y mundial.
} 
exhaustiva, sobre esta producción cinematográfica. El análisis de las obras de Verdaguer, Grueso, Morán, Serrano Azcona y Martín Patino va a mostrar que la variedad de modos documentales - usando el concepto de Bill Nicholsque presentan sus trabajos es síntoma del carácter novedoso del 15-M, el cual no es fácilmente encasillable dentro de una única forma fílmica. La pluralidad defendida como valor por el movimiento de los indignados explica la diversidad de modos representacionales usados en la filmación de este fenómeno histórico. Para profundizar más en esta idea, tesis central del ensayo, el análisis de los documentales se detendrá también en otros aspectos, tales como la transformación del espacio urbano, el derecho a la ciudad, la precariedad como nueva forma de vida, el sujeto de la crisis económica, la resemantización de la cotidianidad, etc. A pesar de sus diferencias internas, en todos los documentales asistimos a la construcción de la ciudadanía como sujeto ético comunitario que encarna la oposición al discurso dominante o, con otras palabras, estamos en un tipo de cine militante y propagandístico que busca construir un discurso revulsivo, articular el malestar de la cultura y encauzar una desbordante energía revolucionaria. También se ve en todos ellos la invocación de la contrainformación como modo de desmentir y superar unas versiones oficiales a las que acusan de manipular la verdad histórica (Benavente, 2012, p. 626).

\section{Documentando el 15-M}

\#Indignados. Del 15M al 20N, de Antón Verdaguer, se estrenó en noviembre de 2011 online en www.docuindignados.com. En el documental se entrevista a unas setenta personas, entre las que se encuentran ciudadanos anónimos, filósofos y artistas (como Julieta Serrano), por lo que en parte responde al modo participativo, el cual destaca por la centralidad del testimonio. Sin embargo, \#Indignados se enclava sobre todo en el expositivo, que "es un modo ideal para transmitir información y movilizar apoyo" (Nichols, 2013, p. 196), contando mediante una clara estructura linear - similar a la del relato 
tradicional de planteamiento, nudo, desenlace- los orígenes, razones, problemas y futuro de este movimiento. Al ser una de las estrategias más útiles para el modo expositivo, la estructura funciona como forma de persuasión que, lejos de ser inocente, esconde opciones de importantes implicaciones ideológicas y políticas: “a documentary's ability to say something about the historical world depends largely on the effectiveness of its structure" (Spence \& Navarro, 2011, p. 114).

El modo expositivo presenta la realidad histórica dentro de un marco retórico que interpela directamente al espectador. En \#Indignados, los actores Montserrat Alcoverro y Alex Casanovas conducen la historia, funcionando su voz en off como actualización de la voz omnisciente tradicional para de esta manera reflejar los valores ideológicos del 15-M. Uno de los rasgos distintivos del modo expositivo es la voz, ricamente entonada y autoritaria, de varón profesionalmente educado, que la audiencia tiene que aceptar (Nichols, 2013, p. 193). Mediante el comentario instructivo e incuestionable, el narrador en tercera persona controla el flujo de información con relación a lo relatado y a la audiencia, a los que trata como mutuamente excluyentes, quedando además la imagen subordinada a la voz — suelen aparecer sincronizadas en los films de ficción- como mero acompañamiento visual (Spence \& Navarro, 2011, p. 248). Por el contrario, en \#Indignados, Alcoverro y Casanovas ofrecen una valoración positiva del 15-M que no se escuda en la objetividad como ejemplifican sus pinceladas de ironía, guardan estrictamente el turno de palabra haciendo uso de la misma cantidad de tiempo como defensa de la igualdad de género, y ambos van vestidos con ropa de un tono de color verde que simboliza tanto el respeto por el medio ambiente (verde) como por la militancia social (militar). Aunque siguen las convenciones del modo expositivo, lo que se muestra sobre todo en las secuencias en las que aparecen en una terraza o azotea mientras que la calle queda abajo ostentación de la superioridad que otorga el poder mirar a la totalidad-, a la vez, como acabamos de ver, replican algunos de los valores proclamados por el 15-M. 
Tras repasar los orígenes históricos del movimiento indignado - Ley Sinde, grupo Anonymous, Democracia Real Ya, redes sociales, nuevas tecnologías, publicación de Indignaos de Stéphane Hesse, revolución silenciosa de Islandia, revueltas de Túnez y Egipto-, \#Indignados repasa algunos hechos clave, como la organización de las plazas y la repercusión en otros países, aportando una gran cantidad de información factual mediante planos, estadísticas, barras, gráficos y técnicas digitales que buscan exponer de manera didáctica los resultados obtenidos por el Estudio de la Universidad de Castilla la Mancha para convencer al espectador. Como es bien sabido, la evidencia en el género del documental es interpretada y organizada por el cineasta, siendo su uso dentro del flujo de información lo que da a esta su coherencia y capacidad de persuasión. Todos los entrevistados, excepto uno, están en espacios públicos. El uso de la cámara en mano, de la steadicam y de los movimientos de cámara resalta la centralidad de las calles y las plazas, cediendo los planos medios de los entrevistados el protagonismo al dinamismo y a la vitalidad de un entorno en el que siempre hay movimiento. La calle es el espacio natural de la historia al haber participado la mayoría de los entrevistados en las acampadas, siendo el rodaje en exteriores, en los mismos lugares donde acontecieron los hechos, una convención formal que funciona como marcador de autenticidad para el espectador.

\#Indignados termina con un interrogante sobre la capacidad de influencia del movimiento en las Elecciones Generales del 20-N (20 de noviembre de 2011), uno de los debates más importantes entre los indignados, quienes llegaron a pedir el voto en blanco e incluso la "papeleta del 15-M"5. Respondiendo a este debate, la última secuencia congrega las opiniones de todos los entrevistados en un gran mosaico que va formándose a medida que las distintas piezas - las pequeñas imágenes de cada uno de ellos- van pegándose una junto a otra hasta llenar todo el plano, subrayando una pluralidad que es intrínseca al 15-M (1:13:12-1-1:18:55). Los documentales juegan con nuestras expectativas, nos hacen preguntas que adelantan el final

5 Los acampados pidieron que se incluyeran en las elecciones, como posibilidad de voto, una papeleta que reflejara las propuestas del 15-M. 
para que los últimos minutos coincidan con la resolución del problema, y comparten así con la ficción el ser un tipo de narración dramática en el que un evento o series de eventos avanzan hacia su resolución, es decir, están ordenados por un coherente sistema de causalidad que responde a una trayectoria teleológica (Spence \& Navarro, 2011, p. 136). La repetición de la conocida canción Palabras para Julia de Paco Ibáñez, que acompaña los títulos de crédito iniciales, cierra el relato de manera circular apostillando en los créditos finales la moraleja de la historia: "tú ya no puedes volver atrás".

15-M "Excelente, Revulsivo, Importante", también conocido como "Excelente, Revulsivo, Importante": una visión muy personal sobre el 15-M, está escrito y dirigido por Stéphane M. Grueso, quien ha declarado "Yo llevo ya 5 o 6 películas y esta ha sido distinta, novedosa, extraña..., vamos 'muy 15M"' (2012, s.p.) ${ }^{6}$. Apostando por el modo reflexivo, que se caracteriza por llamar la atención sobre las convenciones de la representación, este documental busca dar visibilidad al movimiento pro-revolucionario mediante la reafirmación del carácter subjetivo de la propuesta discursiva: un relato propio, una voz personal y una visión que responde a la experiencia del director como una más entre las miles de personas que se echaron esos días a la calle. Esta mirada en primera persona, además de resaltar la heterogeneidad de las movilizaciones, afirma el testimonio como respuesta frente a la desinformación resultante de la instrumentalización periodística, la cual ha sido estudiada con relación a los dos periódicos más leídos en España: El País valoró el 15-M en clave electoral y buscó acercarse a sus postulados para captar votos para el PSOE; El Mundo subrayó su carácter de movilización política de final incierto y se decantó por una deslegitimación que, llegando a relacionar el ideario del movimiento con Bildu, pasó al ataque -carácter poco fundado de sus propuestas, contradicciones, falta de objetivos claros, progresiva desorganización y acefalia- (Pinilla, 2011, pp. 201-7)7. Esta última estrategia periodística no se alejó demasiado de la usada

${ }^{6}$ Este documental forma parte del proyecto transmedia $15 \mathrm{M} . c c$, junto con un libro y una serie de herramientas online, cuyo objetivo es difundir el movimiento 15-M.

7 Bildu es una coalición pro-independentista y nacionalista vasca de extrema izquierda, 
por los poderes fácticos, los cuales estereotiparon a los indignados como “marginales antisistema”, "violentos” y "perroflautas”, marcando una línea divisoria entre lo normal y lo sospechoso, turbio y violento (FernándezSavater, 2012, p. 678).

15-M Excelente es un buen ejemplo de modo reflexivo como forma documental auto-consciente y auto-cuestionante, caracterizándose por un nivel intensificado de reflexión sobre la naturaleza de la representación y por enfrentarse a las técnicas y convenciones del realismo. El carácter artificial, de construcción, de producto que reflexiona sobre su propia forma de hacerse, se muestra desde las primeras secuencias. 15-M Excelente comienza preguntándose qué fue el $15-\mathrm{M}$. El abanico de respuestas que se ofrecen refleja la heterogeneidad del movimiento, propone la heteroglosia - para usar el concepto de Mijaíl Bajtin- como única forma de representación posible, y revela mediante la contraposición de afirmaciones contradictorias la complejidad de lo observado. El título proviene, a modo de homenaje, de una entrevista que hizo la Cadena Ser de radio al economista e intelectual José Luis Sampedro (03: 15). Tras sus declaraciones, el plano secuencia acelerado que se acerca a los toldos de los acampados y se pasea entre ellos muestra que la Historia, durante unas semanas, se va a acelerar, forzándonos a mirarla de maneras diferentes. También aparecen los primeros planos de unos entrevistados que no mueven sus bocas a pesar de que se escuchan sus palabras: la disociación entre la imagen y el sonido nos invita a acercarnos al documental de manera reflexiva. A medida que este avanza se van repasando las causas de la movilización, la creación de la plaza, la manipulación de los medios, la táctica de la desobediencia civil, las experiencias de los protagonistas, el clima de inclusión, el uso de la tecnología, los logros del 15$\mathrm{M}$, la violencia policial contra los indignados y el desmantelamiento de la acampada.

El final del documental vuelve a concentrar estrategias que llaman la atención en el cómo más que en el qué se cuenta, como la figura de un 
anciano que deambula por entre los acampados, cuya imagen sirve al director para ofrecer una reflexión final, en primera persona, sobre cuáles serán en el futuro el significado y la validez de este movimiento, siendo el anciano un símbolo de la sabiduría que da el paso del tiempo. Tras los títulos de crédito aparece un videoclip (1:06:25-1:09:11) que supone la "ocupación” del documental, ya que los productores habían cedido el espacio de los créditos pero no sabían qué se iba a insertar en él: un hombre y una mujer, cada uno con su ordenador, teclean en Google entradas como "y ahora qué hacemos" y "crisis", apareciendo primero Angela Merkel y un indigente rebuscando comida $\mathrm{y}$, a continuación, tras una pantalla en negro, carteles con las acciones del movimiento, gente tomando las calles y letreros de "eXpaña", "declaramos al gobierno irrelevante" y "www.exlandia.net". Como banda sonora suena la canción "La revolución no será televisada", original de Gil Scott-Teron. Se trata por tanto de un videoclip que, mediante un uso lúdico del género del what if, hace real la fantasía de que la revolución sí tenga lugar aunque los canales de televisión, siempre en manos de los poderes fácticos, nunca la vayan a contar. Tras el videoclip aparecen, a manera de guiño, las caricaturas de todos los entrevistados, los cuales son despojados de la autoridad de la palabra y acercados de esta manera al ciudadano de a pie. Tenemos de nuevo la auto-reflexividad como instrumento para crear una consciencia sobre los supuestos formales de la representación. El documental termina avisando de que las cuarenta conversaciones escuchadas se pueden descargar en http://Madrid.15M.cc, convirtiéndose en un film digital interactivo.

En 15M \#Acampadasol: historia de una ciudad, dirigido por Adriano Morán, predomina el modo participativo, el cual se caracteriza por el uso frecuente de la entrevista en primer plano. Las primeras imágenes de $15 M$ \#Acampadasol muestran, mediante un montaje acelerado -personas desplazándose, manos pidiendo la voz, toldos desplegándose-, cómo, en pocos días, las cosas cambiaron a gran velocidad. La música de fondo del concierto para piano opus 30 de Rachmaninoff enfatiza la fuerza y vitalidad 
de las acampadas. El uso de la steadicam subraya el movimiento incesante de la gente. Tras las secuencias iniciales, el documental se construye sobre una gran cantidad de entrevistas a los acampados, los cuales van respondiendo a las preguntas del documentalista. En el modo participativo, “el cineasta actúa con sus sujetos, más que observarlos de manera no intrusiva. Las preguntas se convierten en entrevistas o conversaciones, el involucramiento crece hasta formar patrones de colaboración 0 confrontación" (Nichols, 2013, p. 207). La sensación de presencia física que posibilita el intercambio sonoro sincrónico coloca al realizador en escena, subrayándose el encuentro real, vivido, directo, entre este y el mundo que le rodea. Se enfatiza además la verdad del encuentro entre el realizador y los sujetos, ya que se "hace hincapié en el compromiso ubicado, la interacción negociada y el encuentro emocionalmente cargado" (Nichols, 2013, p. 214), entretejiéndose así lo personal y lo político.

Las entrevistas, todas ellas a acampados como protagonistas verdaderos de la historia y de la Historia, muestran una gran profusión de primeros planos e incluso de primerísimos planos. Con frecuencia las entrevistas filmadas en estudios usan planos medios para mantener una distancia educada con el entrevistado, ya que permiten verle bien la cara y reconocer sus expresiones faciales sin invadir el espacio que le circunda. Los primeros planos, por el contrario, aíslan al sujeto, le otorgan importancia, indican familiaridad y proximidad, insinúan curiosidad y, a veces, pueden incluso sugerir intrusión (Spence \& Navarro, 2011, p. 189). El signo de información enroscado sobre sí mismo como en @ situado en el ángulo derecho superior de la pantalla, presente durante todo el documental, advierte de manera icónica que en los entrevistados se halla la verdadera información sobre el 15-M. Entre éstos se encuentran varios periodistas que muestran una versión de la realidad que contradice la de unos grandes medios que llegaron tarde y mal a Sol. Numerosos entrevistados subrayan la tensión que se produce con algunos medios conservadores, cuando éstos decidieron prestar atención a las acampadas tras el eco que la noticia había alcanzado a nivel internacional, a 
la vez que desmienten la imagen difundida por algunos medios nacionales que hablaron de agresiones, hurtos y drogas.

A través de las entrevistas se va tejiendo el tema principal de $15 \mathrm{M}$ \#Acampadasol que es, como el subtítulo del documental dice, la historia de una ciudad. Matthew Feinberg ha defendido acertadamente que las acampadas fueron un ejemplo emblemático de lo que Henri Lefebvre denomina right to the city, es decir, la lucha contra la apropiación por parte del capitalismo neoliberal de un espacio que pasó a ser reclamado por los indignados para un proyecto horizontal o procomún social, cultural y político (2014, pp. 146-49). Uno de los acampados declara: "somos una forma de gestión de lo público que ha recuperado el espacio público, la plaza, para lo que siempre ha sido un espacio de encuentro de cualquiera y de todos" (59:58). La primera parte del documental cuenta cómo se construyó la ciudad Acampada Sol. Se presenta una topografía del espacio no como empresa monumentalizadora -que incluiría grandes avenidas, estatuas, edificios conocidos-, sino como lugar habitado, es decir, de calles y plazas como sitios para la vida pública. Sol es retratada a través de unos planos a vista de pájaro que muestran cómo la plaza fue transformándose y llenándose de carteles, globos, toldos, tiendas de campaña, etc. Los paneos de cámara enseñan cómo era la vida en esta nueva ciudad en la que la cotidianidad, incluyendo actos tan básicos como comer y dormir, fue reinventada de nuevo. Los entrevistados afirman que es "una pequeña ciudad dentro de la ciudad, una medina, un zoco" (18:06), "un estado dentro del estado, una república" (19:13). El 8 de junio los acampados se desplazaron a los accesos del Congreso de los Diputados para protestar por la reforma laboral, representándose mediante planos con gran profundidad de campo que la "ciudad" Acampada Sol tenía la capacidad de expandirse y ocuparlo todo.

La segunda parte de $15 \mathrm{M}$ \#Acampadasol cuenta el acoso y el desmantelamiento de la "ciudad". Las asambleas se enroscaron y empezaron a no ser productivas, lastrándose la falta de consenso. También se sucedieron 
los enfrentamientos con las fuerzas del orden. Los planos en contrapicado muestran -además del uso de la fuerza por parte de los policías frente a la indefensión de los acampados- a éstos sentados en el suelo, reclamando el uso público del espacio, y a los guardias levantándolos y arrastrándolos, negándoles ese mismo espacio. Un primer plano de un puño con el guante negro reglamentario recuerda a manera de sinécdoque quién tiene el poder. Creando una relación causa-efecto, tras los desalojos vemos a muchos indignados andando por el centro de Madrid y reclamando su derecho al espacio urbano - para lo que se incluyen imágenes de lugares tan conocidos como la fuente de la Cibeles-, en un montaje que reivindica el valor del activismo de los acampados. El 12 de junio se puso fin a la acampada en Sol. El montaje acelerado enseña, de manera similar a la formación de la ciudad al principio del documental, su desmantelamiento. La limpieza de Sol recoger toda la basura, fregar briosamente el suelo- desvela el cuidado de lo público mostrado por los indignados y desmiente la propaganda que circula sobre ellos. En los últimos dos planos una pancarta reza "Nos vemos en los barrios" (1:04:21), mientras que un chico se va con su bici hacia esos barrios: la nueva "ciudad", difusa pero cierta, estará allí donde haya que hacer labor de justicia social.

Falsos horizontes, de Carlos Serrano Azcona, es la segunda parte de un díptico que comienza con Banderas Falsas (2011), documental que trabaja con diferentes texturas, ratios y formatos, desde el HD hasta teléfonos móviles. Aunque puede considerarse que Banderas falsas es la imagen y Falsos horizontes es la palabra, el primer film agrupa encuentros multitudinarios que responden a razones muy variadas y diferentes del $15-\mathrm{M}$ -mundial de fútbol de 2010, movilizaciones en México contra la privatización del petróleo, procesiones de Semana Santa. Su objetivo confeso es rodar y acumular un archivo de imágenes históricas (14:00). Falsos horizontes, por su parte, se caracteriza por una hibridez que combina el modo participativo, que enfatiza la conversación con los protagonistas históricos, el modo expresivo, que subraya la visión subjetiva del cineasta, y 
el modo poético, que destaca por su vívida cualidad expresiva. Como acabamos de ver, el modo participativo busca la verdad del encuentro entre el documentalista y los entrevistados. Entre éstos destaca la capacidad de expresión del joven del flequillo largo que está fumando, el hombre derrotado que está en paro y sin casa, y la chica de diecisiete años que aún mantiene la esperanza. Se trata de ejemplos de vidas precarias o vidas subprime, para utilizar la expresión de Germán Labrador (2012, p. 557). El modo expresivo rechaza la representación realista y acentúa la complejidad emocional de la experiencia mediante libertades poéticas, estructuras narrativas poco convencionales y formas subjetivas de representación. La perspectiva personal del realizador, muy marcada, intenta dar representación a una subjetividad social que une lo individual con lo colectivo, apelando al sentimiento más que a la razón. Se subraya así "la complejidad de nuestro conocimiento del mundo, al enfatizar sus dimensiones subjetivas y afectivas" (Nichols, 2013, p. 229). Finalmente, el modo poético pone énfasis en recursos como la fragmentación y la ambigüedad para dar al mundo histórico una integridad formal y estética peculiar: "el compromiso del cineasta es para con la forma de la película” (Nichols, 2013, p. 187).

Falsos horizontes comienza con una música electrónica no diegética con efectos sonoros cercanos al estilo death metal encaminada a crear un tono sombrío, el cual queda reforzado por la oscuridad de las primeras imágenes, rodadas por la noche en Sol. Ambos, tono sombrío e imágenes oscuras, permean -al igual que en Banderas falsas - todo el documental. El título juega con la ambigüedad, apuntalando la negatividad del punto de partida: 1) las expectativas de vida de los jóvenes españoles que con la crisis económica vieron derrumbarse sus sueños han resultado ser falsas, 2) las esperanzas de que el 15-M se convirtiera en una revolución total estaban destinadas al fracaso. El tono laudatorio que encontramos en los otros documentales está aquí ausente. El primer entrevistado, un hombre con sombrero, adelanta la necesidad de la movilización como idea central del film: hay que movilizarse porque, aunque al final no se consiga nada, la experiencia de la lucha es lo 
único que el sistema no puede quitarte, "Estamos derrotados, ¿de acuerdo?, es decir, la victoria del poder es total, pero hay que luchar hasta el final, hay que luchar hasta el final" (oo:06-00:30). Los primerísimos planos del hombre del sombrero, que mira directamente a cámara, sugieren que la información que nos da es importante, refuerzan la pasión con la que nos habla, y acentúan la interpelación constante al espectador mediante la muletilla “¿de acuerdo?”. En la siguiente entrevista, a un hombre extranjero de cierta edad, destaca la utilización de un plano holandés, el cual suele usarse para añadir dinamismo pero también inestabilidad a la imagen: los falsos horizontes del título. La falta de una clara estructura narrativa, y por tanto de conclusión, contribuye a cerrar desde el principio la posibilidad de resolución o mejora. El contraste, técnica muy utilizada (junto con la comparación) en el género documental, se suma a los recursos anteriores.

El contraste crea una incongruencia consciente y deliberada que nos insta a comparar dos términos. La disonancia provocada por la yuxtaposición genera una pintura mental que va más allá de los sonidos e imágenes inmediatos y, al crear una distancia entre los términos usados, agudiza las diferencias entre ellos (Spence \& Navarro, 2011, pp. 119-20). En varias imágenes se nos muestra a los acampados tocando tambores, desfilando y bailando en un despliegue de alegría esperanzada; sin embargo, las imágenes fueron rodadas por la noche. Algunos niños hacen grandes pompas de jabón que se elevan hacia el cielo; pero ese mismo cielo es invadido por un helicóptero que vigila a los acampados recordándoles que el sistema les vigila como un gran panóptico -para usar el concepto de Michel Foucault. El helicóptero funciona de hecho como un leitmotiv en Banderas falsas y Falsos horizontes, creando un vínculo de continuidad entre ambos trabajos. Un hombre se pasea con el chaleco amarillo de "Compro oro", que ha proliferado tristemente desde la crisis; pero entre los indignados no parecía haber nadie que tuviera mucho oro que vender. Los planos de los tejados de los edificios muestran el cielo abierto como horizonte sin límites; aunque los indignados, a quienes se les había sustraído su horizonte, aparecen sentados bajo unos 
toldos bajos y tupidos que impiden ver el más mínimo resquicio de cielo. El documental abunda en tipos que parecen peculiares a primera vista, como el hombre de larga barba y enorme crucifijo delante de la furgoneta "El extranjero solitario"; pero todos cuentan historias que se han convertido en demasiado corrientes. Uno de los entrevistados afirma que todos ellos son "la voz del pueblo" (58:53) en un plano que tiene como fondo, simbólicamente, la Plaza Mayor; sin embargo, tras la marcha/cacerolada que tuvo lugar frente al Consistorio del Ayuntamiento, reaparece la mirada vigilante del helicóptero. Se suceden los desalojos y cargas policiales. De nuevo el helicóptero, en un montaje paralelo. La cámara, desde un ángulo nadir, hace un zoom de aproximación que se va pausando, creando un agudo sentimiento de intranquilidad en el espectador que confirma la importancia, en los modos expresivo y poético, de los "tonos evocativos y sombreados expresivos que constantemente nos recuerdan que el mundo es más que la suma de la evidencia visible que derivamos de él” (Nichols, 2013, p. 234). Falsos horizontes termina con el grito, frente a la puerta del Congreso, en plena noche, de "Viva la revolución" (1:22:05): el único horizonte no falso es la lucha antisistema.

Libre te quiero, del conocido cineasta Basilio Martín Patino, es un magnífico ejemplo de documental observacional, el cual intenta responder a la pregunta formulada por Nichols “¿Qué (sic), si el cineasta se dedicara a simplemente observar lo que ocurre frente a la cámara, sin una intención abierta?” (2013, p. 199). El objetivo del modo observacional es que la imagen lleve de manera directa al espectador lo que ha pasado. En la página web de la Fundación Basilio Martín Patino se aclara

Para esta ocasión, Patino ha decidido adoptar un nuevo estilo, impresionista y próximo a otros esfuerzos de documental puro, dejando que las imágenes se expliquen por sí solas, sin comentarios, entrevistas a cámara o texto en off explicativo alguno (...). La película, después de dar fe de lo ocurrido, sin 
mediación o intención, dejando que las imágenes hablen, termina con el final de la experiencia 8 .

Como fondo, los versos de Agustín García Calvo -amigo personal del realizador e inspiración para el título- "Libre te quiero... pero no mía", musicados por Amancio Prada, confirman la intención de Martín Patino: transmitir, sin apropiárselas, unas imágenes que se quieren libres. La elección de este modo documental responde a la génesis del proyecto. Patino, que vivía cerca de Sol, salió a la calle el mismo 15 de mayo al oír a los manifestantes, y al día siguiente ya estaba embarcado en un trabajo que conjuga la labor de su equipo con imágenes filmadas por los mismos acampados. Libre te quiero no tiene voz en off, voz narrativa, guion, diálogos, trama argumental, orden lineal, declaraciones a cámara, ni material de archivo, ya que se trata solamente de un montaje excelente que se apoya en la fuerza de las imágenes. Las reseñas que se publican a su estreno destacan: "Es un documento impresionante, cine puro, historia pura, vida pura", "es sencillamente un prodigio; un relámpago de honestidad, claridad y emoción”, "un documento que se impone como un torrente de fuerza y de libertad cinematográfica"9.

Libre te quiero representa el 15-M resaltando el carácter festivo, la alegría, la felicidad, la intensidad y la vitalidad contagiosas que se vivieron en las acampadas ${ }^{10}$ :

la película discurre por la retina del espectador con la única y clara intención de recuperar un simple instante. Y ésa es la virtud, y antídoto contra pesados y perezosos, de Libre te quiero. Importa la belleza de un momento capturado en su plenitud (la 'epojé' que decían los fenomenólogos), sin más ideología que la de la propia belleza. La belleza, otra vez, del simple instante. No hay más ${ }^{11}$.

\footnotetext{
8 http://www.basiliomartinpatino.org/filmografia/libre-te-quiero/ 9 http://www.basiliomartinpatino.org/filmografia/libre-te-quiero/

10 Martín Patino ha declarado: "Fueron días muy intensos, no dábamos abasto para rodar todo lo que teníamos que rodar. En Madrid, idonde nunca pasaba nada! Todo se transformó y la ciudad se llenó de alegría. Madrid dejó de ser Madrid" (http://www.culturaenaccion.com/libre-te-quiero-15m/).

${ }^{11} \mathrm{http}: / /$ www.elmundo.es/elmundo/2012/10/21/cultura/1350821970.html
} 
Para ello, Libre te quiero representa el 15-M de forma claramente idealizada. La película arranca con la confluencia de los manifestantes, una riada de personas de toda edad y condición, en la Puerta del Sol al ritmo de batucadas, canciones populares y consignas. Ya en estas primeras imágenes destaca la extraña simpatía hacia los indignados que parecen mostrar los policías encargados de vigilarlos, contagiados del ambiente festivo. La generosidad declara la caducidad de las lógicas del individualismo y del confort del capitalismo avanzado en una nueva cotidianidad en la que se reparte comida gratuita, se comparte el agua, se duerme en sacos de campaña en un espacio compartido y se establecen espacios comunes (guardería, biblioteca), todo ello sobre la base de la buena voluntad. La amabilidad guía la reorganización del espacio para acomodar las sugerencias de los comerciantes de la zona. La estética destaca por su colorido y luminosidad, como si el 15-M hubiera devuelto el color y la luz a una sociedad en blanco y negro, siendo fundamental en este sentido el trabajo del colorista audiovisual. Para subrayar la alegría y la vitalidad de las movilizaciones, Martín Patino elige como sujeto privilegiado de la historia a jóvenes y a madres con niños. Además, resalta la creatividad que surge por todas partes adoptando una gran variedad de formas, desde carteles a objetos de arte, pasando por bailes, disfraces, conciertos, juegos para niños, etc. Esa misma creatividad ha sido estudiada por Nuria Pérez Vicente a propósito de los slogans del 15-M, en los cuales la evidente intención retórica presentaba, además de una fuerte finalidad persuasiva, una forma de subversión lingüística encaminada a romper los tradicionales esquemas comunicativos (2013, s.p.). En una de las secuencias más llamativas, una joven sentada en el suelo, a un palmo de las botas de cuero de un antidisturbios, juega con un globo que sube y baja $\mathrm{y}$, arriesgándose a recibir un golpe en cualquier momento, sigue allí sonriendo, inmersa en su mundo de luz y color.

Casi al final de Libre te quiero, entre los minutos 21:55 y 24:04 de la segunda parte, aparecen una serie de fotografías de diferentes familias en el interior de sus viviendas, cuyo estatismo contrasta fuertemente con la vitalidad de los 
acampados. La inmovilidad de los retratados denuncia la pasividad de todos aquellos que en vez de salir a las calles se quedaron en el salón de su casa a ver las movilizaciones por la televisión, como sugieren las pantallas que proyectan imágenes del movimiento en cada una de las fotografías. El extrañamiento que provocan estas figuras que miran, congeladas, a la cámara, invita a reflexionar sobre la naturaleza de la representación. La fotografía ha sido utilizada tradicionalmente en el cine como fuente de evidencia visual (Spence \& Navarro, 2011, p. 39), dentro de una forma tradicional de entender el documental como representación auténtica de la realidad sociohistórica, la cual encajaría como un guante con el documental observacional $^{12}$. Esto nos lleva a los terrenos de la ética de la representación. Frente a esta creencia común, las imágenes -fotografías en este caso- nos recuerdan la naturaleza convencional de la representación documental. Los retratos de las familias son una forma de responder a los problemas éticos que plantea el documental en general, y el modo observacional en particular. Este es también conocido como direct cinema, ya que intenta transmitir la inmediatez del evento a un espectador privilegiado, quien tiene la impresión de estar mirando de cerca los sujetos del film sin ser notado, a la vez que está tentado de aceptar la transparencia de la imagen como si estuviera viendo la situación de primera mano (Spence \& Navarro, 2011, pp. 194-97). Sin embargo, filmar algo como si se estuviera ausente invita a debatir sobre si lo que vemos sería lo mismo, y hasta qué punto, si el documentalista no estuviera allí (2013, 206). Martín Patino responde a esta objeción ética mediante unas extrañas fotografías que interrumpen bruscamente el flujo del documental y quedan sin explicar: "El retiro del cineasta a la posición de observador apela al espectador a asumir un papel más activo al determinar la significación de lo que se dice y hace" (Nichols, 2013, p. 201). A pesar de ello, Libre te quiero ofrece unos destacados efectos retóricos, en el material seleccionado y el tratamiento del mismo, que claramente pintan un retrato del 15-M con los colores de la amabilidad.

12 "Photos functioned as tools to analytically record life and sources of visual evidence". 
Aunque en los cinco documentales analizados se repiten numerosos planos casi idénticos - manos en alto de los indignados, paneos de pancartas y toldos, Sol a vista de pájaro- que pudieran hacer pensar que estamos ante el mismo tipo de representación, el análisis ha mostrado que se trata de visiones muy diferentes del 15-M. \#Indignados. Del 15M al $20 \mathrm{~N}$ presenta de manera expositiva una amplia información sobre la acampada en Sol; 15M: "Excelente, Revulsivo, Importante" dirige la mirada del espectador de manera reflexiva y auto-consciente hacia sus propios mecanismos de representación; \#Acampadasol: historia de una ciudad opta por dar voz a los acampados para reflejar el espíritu participativo de este movimiento; Falsos horizontes se decanta por la hibridez y combina los modos participativos, expresivo y poético; y Libre te quiero recrea, y se recrea en, la belleza de esos días mediante un film observacional. Como estos documentales ejemplifican, la producción de la cultura visual de un evento histórico es un proceso colectivo en el que están igualmente implicados productores, sujetos y consumidores de la imagen. Esta producción documental es un testimonio histórico, residiendo su poder retórico en su capacidad para representar el 15-M como evento y discurso. Se trata, como hemos visto, de una construcción discursiva abierta, colectiva y urgente que incluye buenas dosis de documentalización, pero también, en numerosos casos, de mitificación de unas imágenes que tienen el poder de convertirse en icónicas.

\section{Referencias bibliográficas}

Alonso, V. (2016). Clase Valiente. España: Compacto / Fractal 7.

Barriga, C. (2013). Tres instantes, un grito. España / Chile: Barriga / Otero Roth / Fernández.

Benavente, F. (2012). Formas de resistencia en el documental español contemporáneo: en busca de los gestos radicales perdidos. Hispanic Review, 80 (4), 607-29. 
Cameron, B. (2014). Spain in Crisis: 15-M and the Culture of Indignation. Journal of Spanish Cultural Studies, 15 (1-2), 1-11. Disponible en: dx.doi.org/10.1080/14636204.2014.1002601.

Labrador Méndez, G. (2012). Las vidas subprime: La circulación de historias de vida como tecnología de imaginación política en la crisis española (2007-2012). Hispanic Review, 80 (4), 557-55.

Feinberg, M. (2014). Don Juan Tenorio in the Campo de Cebada: Restaging Urban Space After 15-M. Journal of Spanish Cultural Studies, 15 (12), 143-59.

Fernández-Savater, A. (2012). El nacimiento de un nuevo poder social. Hispanic Review, 80 (4), 667-81.

George, S. (2013). Vers Madrid. España / Francia: Noir Production.

Grueso, S. (2012). 15M: "Excelente, Revulsivo, Importante”. España: Madrid. 15M.cc.

Grueso, S. (2012). Ya ha nacido, se llama 15M: "Excelente. Revulsivo. Importante" y pesa 74 minutos. El diario.es. Disponible en: https://www.eldiario.es/interferencias/estreno_15Mcc_documental_ 6_75652439.html

Güell Fleck, L., Oriola i Folch, J. (2012). El despertar de les places. Un any de 15M. España: TransformaFilms.

Jornet Somoza, A. (2016). Cinco años después del 15-M: narrativas de la crisis económica y política. Cuatrocientos cincuenta y dos grados Fahrenheit, 15, 1-4. Disponible en: www.452f.com/editorial15.

Lacuesta, I. (2012). La matança del porc. España / USA.

Lacuesta, I. (2014). Murieron por encima de sus posibilidades. España: Ad hoc studios / Alicorn Films / ICO.

Lara, A. L. (2016). Virgil Starkwell en la Puerta del Sol: públicos en revuelta, políticas hacia el ser por venir. Hispanic Review, 80 (4), 651-65.

Martín Patino, B. (2012). Libre te quiero. España: La linterna mágica.

Morán, A. (2011). 15M \#Acampadasol: historia de una ciudad. España: LaInformación.

Moreno-Caballud, L. (2012). La imaginación sostenible: culturas y crisis económica en la España actual. Hispanic Review, 80 (4), 535-55.

Nichols, B. (2013). Introducción al documental. Universidad Nacional Autónoma de México. Disponible en: www.librosoa.unam.mx/handle/123456789/272.

Pérez Vicente, N. (2013). El lenguaje político del 15-M: hacia una nueva retórica de la indignación. Signa: Revista de la Asociación Española de Semiótica, 22, 569-94. 
Pinilla García, A. (2011). La percepción del movimiento "15-M" en las ediciones digitales de El Mundo y El País. Tejuelo, 12, 196-217.

Portabella, Pere. (2016). Informe General II. España: Films 59.

Serrano Azcona, C. (2011). Banderas falsas. España: Estar ahí cinema.

Serrano Azcona, C. (2013). Falsos horizontes. España: Estar ahí cinema.

Spence, L., Navarro, V. (2011). Crafting Truth: Documentary Form and Meaning. New Brunswick: Rutgers UP.

Verdaguer, A. (2011). \#Indignados. Del 15M al 20N. España. Camelo Colectivo / Nao Cinematográfica / 21 de Noviembre P.A. 